Dunamis: Jurnal Teologi dan Pendidikan Kristiani

Volume 4, Nomor 1 (Oktober 2019)

ISSN 2541-3937 (print), 2541-3945 (online)

http://www.sttintheos.ac.id/e-journal/index.php/dunamis

Submitted: 8 Juli 2019

Accepted: 3 Oktober 2019

Published: 28 Oktober 2019

\title{
Apologetika Alkitabiah tentang Penciptaan Alam Semesta dan Manusia terhadap Kosmologi Fengshui sebagai Pendekatan dalam Pekabaran Injil
}

\author{
Hannas \\ Program Studi Doktor Teologi STT Internasional Harvest Tangerang \\ hannas@hits.ac.id \\ Rinawaty \\ Program Studi Teologi STT Internasional Harvest Tangerang \\ rinawaty@hits.ac.id
}

\begin{abstract}
Fenghui's cosmology has penetrated people's understanding and this must be confronted with apologetics originated from the Bible. This study found three main things. First, the universe was created by God and God is personal. Second, humans are created by God but humans are not God. Third, the universe is not eternal, therefore anything that is sought to obtain a longer life as taught through Fengshui's cosmology is futile. Humans seek eternal life, this is only possible through receiving the forgiveness of Jesus Christ. The method used in this study is presuppositions based on the Bible to present objective truths. Presuppositions are supported by various related literature that addresses this theme is certainly placed under the authority of the Bible.
\end{abstract}

Keywords: apologetics; nature; origins; Fengshui; humans

\begin{abstract}
Abstrak
Kosmologi Fenghsui telah merambah dalam pemahaman masyarakat, hal ini harus dihadapi dengan apologetika yang bersumber dari Alkitab. Penelitian ini menemukan tiga hal utama. Pertama, alam semesta diciptakan oleh Allah dan Allah itu berpribadi. Kedua, manusia diciptakan oleh Allah tetapi manusia bukanlah Allah. Ketiga, alam semesta tidak bersifat kekal, sehingga apa pun yang diupayakan untuk memperoleh hidup yang lebih lama (long life) seperti yang diajarkan melalui kosmologi Fengshui adalah kesia-siaan. Manusia mencari hidup yang kekal, hal ini hanya dimungkinan melalui menerima pengampunan Yesus Kristus. Metode yang digunakan dalam penelitian ini adalah presuposisi yang didasarkan pada Alkitab guna menyuguhkan kebenaran yang obyektif. Presuposisi didukung oleh berbagai literatur terkait yang membahas tema ini, tentu ditempatkan di bawah otoritas Alkitab.
\end{abstract}

Kata Kunci: apologetika; alam; penciptaan; Fengshui; manusia 


\section{PENDAHULUAN}

Fengshui telah merambah luas menembus batas-batas budaya dan agama. Dan karenanya Fengshui menghambat pertumbuhan iman orang percaya karena Fengshui mengugat hakekat dan otoritas kebenaran. ${ }^{1}$ Untuk itu diperlukan pola penjernihan iman bagi orang Kristen dan pola peyakinan yang tepat dalam pemberitaan Injil kepada orang-orang yang dipengaruhi oleh Fengshui.

Pola penjernihan Injil yang dapat digunakan untuk orang Kristen yang terpengaruh oleh Fengshui adalah melalui pengajaran tentang hakekat kebenaran dan melalui pengajaran tentang tujuan hidup orang percaya. Sementara pola peyakinan Injil yang dapat digunakan untuk memberitakan Injil kepada penganut Fengshui adalah kerinduan terhadap alam yang harmonis sebagai titik kontak dan pencarian nasehat untuk selamat sebagai penolak malapetaka sebagai titik kontak.

Penelusuran terhadap ajaran Taois dan aspek-aspeknya yang kemudian mempengaruhi Fengshui adalah perlu untuk menemukan corak pikir dasar yang

\footnotetext{
${ }^{1}$ Rinawaty, Apologetika Kristen Terhadap Kosmologi Fengshui, ed. Hannas (Tangerang: Yayasan Kharis Indonesia, 2017), 124.
}

melandasi keyakinan Fengshui. Hal ini juga memungkinkan penilaian yang kritis terhadap ajaran Fengshui dan pengembangan terapan-terapannya dalam kehidupan di masa kini. Karena dasar dari sebuah filosofi adalah sejarahnya.

Kejadian pasal 1-10 mengungkap dasar-dasar kosmologi yang kokoh dan dapat dipertanggung-jawabkan karena sesuai dengan kenyataan yang ada. Kosmologi Alkitab yang dibangun dari Kejadian pasal 1-10 inilah yang diketengahkan untuk menjernihkan pemahaman yang keliru terhadap Allah, alam dan kekekalan bagi umat Kristiani yang terpengaruh oleh Fengshui. Kosmologi ini juga menjadi dasar dan acuan bagi apologetika terhadap mereka (di luar iman Kristen) yang meyakini Fengshui.

Sasaran utama dari apologetika Kristen adalah untuk menciptakan iklim intelektual dan imaginasi yang kondusif bagi tumbuh dan terpeliharanya iman di dalam kepenuhan dan kekayaannya. ${ }^{2}$ Apologetika memiliki tugas dalam dua medan yang berbeda. Yang pertama adalah dalam dunia orang yang belum percaya dan yang kedua adalah di tengah-tengah orang percaya. Beberapa

\footnotetext{
${ }^{2}$ Alister E. McGrath, Bridge Building: Efective Christian Apologetics (England: Hodder and Stoughton Ltd., 1992), 239.
} 
apologet membagi tugas apologet menjadi beberapa bagian. Rahmiati Tanudjaja memaparkan bahwa tugas berapologetika menurut Frame dan Edgar C. Powell meliputi tiga tugas penting, yakni pembuktian atau penunjukkan, pertahanan atau pembelaan dan penyingkapan. ${ }^{3}$

Pembuktian atau penunjukkan berarti memaparkan dasar rasional bagi iman Kristen (1 Kor. 15:1-11); pertahanan atau pembelaan berarti menjawab sanggahan-sanggahan orang tidak percaya terhadap iman Kristen (Fil. $1: 7,16)$; sementara itu penyingkapan merupakan usaha menyingkapkan kesalahan atau kesalah-pahaman dari pemikiran atau pemahaman orang tidak percaya terhadap kekristenan (1 Kor. 1:18-2:16). Frame mengatakan bahwa dalam pelaksanaannya, ketiganya tidak berdiri sendiri dan dapat digunakan sebagai penginjilan. Tujuan penulisan adalah untuk menjelaskan pendekatan perkabaran Injil yang dapat diterapkan setelah menggugurkan konsep kosmologi Fengshui.

\section{METODE PENELITIAN}

Metode yang digunakan peneliti

\footnotetext{
${ }^{3}$ Rahmiati Tanudjaja, "Apologetika Kristen : Tanggung Jawab Semua Anak Tuhan," Veritas : Jurnal Teologi dan Pelayanan 6, no. 2 (October 1, 2005): 229-238.
}

dalam penelitian ini, ada dua. Pertama, metode deskriptif yaitu menjelaskan dan menuturkan masalah apa adanya sesuai bukti yang memadai. Kedua, metode preskriptif yaitu mengusulkan solusi atas masalah yang diuraikan. Dalam hal ini penulis mengoperasionalkan kedua metode tersebut dengan prosedur penelitian kualitatif yaitu dengan mencari sumber data tertulis atau penelaahan.

Obyek dari penelitian ini adalah para penganut ajaran Fengshui dan juga orang-orang percaya (beriman kepada Yesus Kristus). Sumber data dari penelitian ini adalah buku, observasi lapangan. Metode berapologet yang dipergunakan dalam penelitian ini adalah metode presuposisi dikarenakan peneliti berprasangka atau menilai kosmologi Fengshui dari perspekftif Alkitab, sehingga semua pemahaman dan pengalaman dalam ranah Fengshui diukur atau dihakimi oleh Alkitab. Tidak ada suatu pemikiran pun yang benarbenar obyektif, itulah sebabnya menjadi keharusan bagi orang Kristen untuk mempertimbangkan presuposisipresuposisi dalam melakukan apologetika. $^{4}$

\footnotetext{
${ }^{4}$ Scott R. Burson, The New International Dictionary of New Testament Theology Vol. 1 (Grand Rapids, Michigan: Zondervan Publishing Company, 1998), 144.
} 


\section{HASIL DAN PEMBAHASAN}

\section{Deskripsi Fengshui}

Kekuatan sentrifugal (Yin) dan kekuatan sentripetal (Yang) haruslah seimbang jika tidak seimbang, tak terjadi apa-apa. Jadi Yin dan Yang adalah asal perubahan dan transformasi, serta akar permulaan dan akhir. $^{5}$ Manusia dan ciptaan lainnya berubah dan bertransformasi secara dinamis; tak satu pun di alam semesta bersifat statis atau lengkap; semua berubah karena polarisasi tak bermula dan tak berakhir.

$$
\text { Konsep ini berdasar pada }
$$
keyakinan metafisis Taois yang mengatakan bahwa Tao adalah asal asali dan pemersatu segala sesuatu dan bahwa alam semesta adalah manifestasi dari Tao, dan Tao ada dimana-mana. ${ }^{6}$ Fengshui berdasar dari ajaran Tao yang menyelami kekuatan alam ${ }^{7}$ atau menjadi energi yang berinteraksi sehingga terjadi perciptaan. Para penganut Fengshui memiliki pemikiran bahwa penciptaan itu terjadi dengan sendirinya sebagai

${ }^{5}$ Ching Ni Hua, Tao: Pedoman Hidup Selaras Dengan Hukum Alam (Jakarta: Pustaka Delapratasa, 1997), 4.

${ }^{6}$ Liliana Too, Fengshui: Memasuki Dunia Naga Dan Macan Membagi Rahasia Di Tycoon Bisnis Di Asia (Jakarta: PT. Elex Media Komputindo, 1984), 13.

7 "Fengshui - Pengetahuan Atau Kepercayaan?," accessed October 20, 2019, https://interiorkantor.com/fengshui-pengetahuanatau-kepercayaan/. interaksi dari energi. Penciptaan yang terjadi dengan sendirinya di sini, bukanlah penciptaan dalam konsep kosmologi kaum evolusionis. Penciptaan ini berdasar pada filosofi bahwa Allah itu adalah kekuatan atau energi, dan tentu saja dengan demikian Pencipta itu tidak berpribadi.

Bila memperhatikan filosofifilosofi ini maka dapatlah disimpulkan bahwa filosofi Fengshui merupakan campur baur antara Monisme-Pantheisme yaitu Monisme yang paling sederhana seperti yang dijabarkan oleh Brow kepada Politheisme dan Humanisme Kosmis. $^{8}$ Monisme adalah suatu kepercayaan bahwa semua yang ada adalah satu. ${ }^{9}$ Semua saling berkaitan satu dengan yang lain saling bergantung dan saling berpenetrasi. Pada puncaknya tidak ada lagi perbedaan antara Allah, manusia, tomat, meja atau sebuah batu karang. Semua adalah bagian dari realitas yang berlanjut, yang tidak ada batasnya, tidak ada pembagian yang tegas. Di sinilah monisme ini menjadi Pantheisme. Namun Brown mengusulkan agar Taoisme Lao-tzu dikategorikan sebagai

\footnotetext{
${ }^{8}$ Robert Brow, "Religion of China," in The Great Asian Religions An Anthology (New York:

MacMillan Publishing Company, 1986), 84.

${ }^{9}$ Douglas Groothuis, Membuka Topeng Gerakan Zaman Baru (Jakarta: Stephen Tong Evangelistic Ministries International, 1996), 18.
} 
Pantheisme yang lebih rapuh, yaitu modified Pantheism. ${ }^{10}$ Jadi modified Pantheism yang adalah bentuk baru dari campuran Monisme dan Pantheisme akan tetap saling terkait, bergabung dan berpenetrasi.

\section{Dunia Diciptakan Oleh Allah dan}

\section{Allah Itu Berpribadi}

Presuposisi yang akan disampaikan disini adalah bahwa dunia ini ada karena diciptakan oleh Allah. Ia bukan hanya mengadakan dunia tetapi bahwa Allah Sang Pencipta itu Berpribadi adanya. Ajaran Fengshui tentang penciptaan perlu dinilai dengan kritis karena menolak hakekat penciptaan itu telah terjadi dalam ruang dan waktu. Penciptaan dalam filosofi Fengshui terjadi dengan sendirinya. Penciptaan dipandang sebagai perluasan energi tak nyata ke arah luar dari pusat. Ketika "organisasi" dari energi tak nyata terbentuk, organisasi ini menghasilkan pengutuban energi yang menjadi dua kelompok yang disebut Yin dan Yang.

Sesungguhnya, dunia ini memiliki titik mula. Dunia diciptakan oleh Khalik yang Agung dan kekal adanya. Dan Pencipta itu berkenan untuk mengkomunikasikan atau

\footnotetext{
${ }^{10}$ Brow, "Religion of China," 84
}

memberitahukan kepada manusia tentang apa yang telah dilakukan-Nya. Pengenalan tentang diri-Nya dan karyaNya dalam penciptaan diwahyukan kepada manusia dan dicatat dalam kitab Kejadian. Karena itu melalui kitab inilah manusia akan beroleh informasi yang tepat tentang karya pencipta-Nya.

Kitab Kejadian menyaksikan bahwa penciptaan dunia merupakan fakta sejarah. Kitab Kejadian menekankan kepada pelaku dari peristiwa penciptaan tersebut. Namun kata "pada mulanya Allah menciptakan langit dan bumi" (Kej. 1:1) juga menunjuk akan permulaan dari segala sesuatu yang ada, bahkan permulaan dari waktu itu sendiri. Tidak ada apapun yang telah ada kecuali Allah itu sendiri. Karena itu juga materi dan benda-benda yang lain tidak kekal adanya. Jadi pada suatu waktu tertentu Allah menciptakan dunia ini. Ia menciptakan dimensi ruang dan waktu. Dan pada waktu itu segala sesuatu yang bukan Allah memperoleh eksistensinya dari Allah.

Penciptaan merupakan tindakan yang Allah lakukan berdasarkan pada kehendak Allah sendiri. Allah mencipta bukan karena Ia terdesak atau karena Ia bergantung terhadap ciptaan-Nya atau juga bukan karena pertimbangan dari luar 
diri Allah. Penciptaan adalah suatu tindakan bebas dari Allah.

Alkitab juga mengajarkan bahwa penciptaan merupakan karya dari Allah Tritunggal. Ayat-ayat Alkitab yang meneguhkan kesaksian tersebut adalah Kejadian 1:26; 3:22; Yohanes 1:1-3; 1415; Kolose 1:15-17. Allah Tritunggal yang ada pada pra penciptaan merupakan tiga pribadi Allah yang saling berinteraksi. Jika eksistensi ini tidak ada, maka penciptaan harus dipandang sebagai sebuah tindakan keterdesakan Allah. Ini berarti Allah berhutang budi pada ciptaan-Nya.

Alkitab juga menyaksikan bahwa Allah menciptakan dunia ini melalui firman-Nya. Kejadian pasal 1 berulangulang mencatat pola "Berfirmanlah Allah" sampai sembilan kali dalam setiap tindakan penciptaan yang dilakukan Allah. Yohanes 1:1-3,14 dan Ibrani 11:3 serta Kolose 1:16 memperjelas bahwa Firman itu telah menjadi manusia dalam pribadi Yesus Kristus dan bahwa di dalam Yesuslah segala sesuatu telah diciptakan, dan bahwa segala sesuatu telah diciptakan oleh Yesus dan untuk Yesus. Kemudian bahwa karya penciptaan itu hanya dapat dimengerti di dalam iman. Namun penting untuk dilihat disini bahwa penciptaan itu bukanlah sesuatu yang dibuat dari diri Allah. Ciptaan bukan merupakan bagian dari diri Allah atau sesuatu yang keluar dari Allah.

Telah disinggung sebelumnya bahwa eksistensi Allah dan eksistensi ciptaan adalah berbeda. Kepribadian Allah dan kepribadian manusia sebagai satu-satunya makhluk yang berpribadi juga berbeda. Allah bereksistensi melampaui ruang dan waktu serta tanpa penyebab, tanpa awal dan tanpa akhir. Tetapi eksistensi manusia terbatas oleh ruang dan waktu, itulah sebabnya ruang dan waktu itu diadakan sebelum manusia itu ada (Kej. 1:1).

Mengenai kepribadian Allah dan manusia berikut pemaparan Schaeffer bahwa Allah adalah Allah yang berpribadi dan yang tak terbatas.

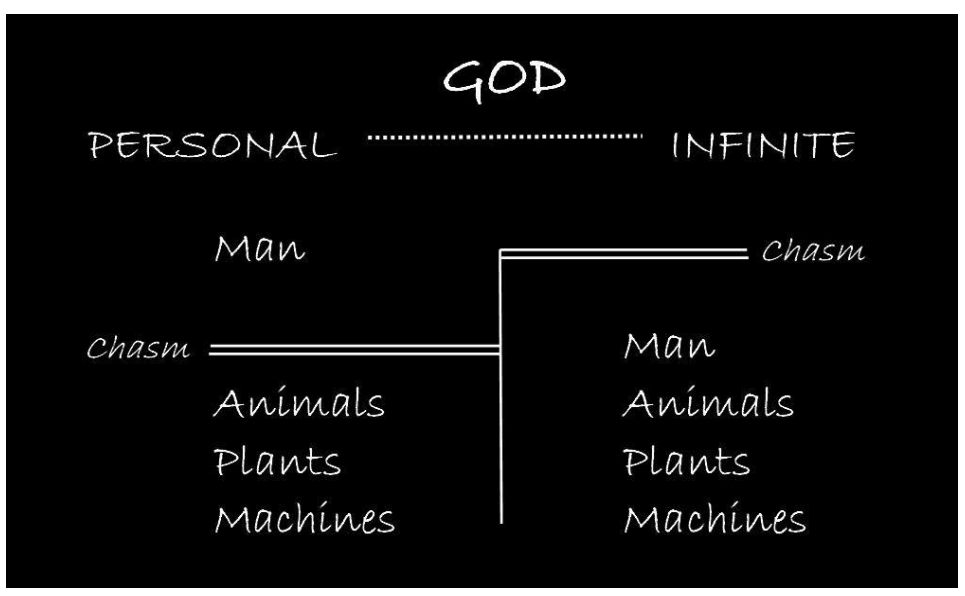

Jika dipandang dari sisi tidak terbatasnya Allah, maka ada jurang pemisah antara Allah dan semua ciptaan-Nya. Karena ciptaan terbatas dan Pencipta tidak 
terbatas. Dari sisi ini manusia tidak berbeda dengan semua ciptaan Allah yang lain. Semua ciptaan ada di dalam area keterbatasannya. Tetapi dari sisi kepribadian, keberadaan Allah sebagai Allah yang berpribadi inilah yang telah menempatkan manusia jauh lebih tinggi dari ciptaan yang lain. Jika saja manusia menolak keberadaan Sang Pencipta yang berpribadi atau dengan mengatakan bahwa penciptaan dimulai dari sesuatu yang tidak berpribadi maka kesimpulannya adalah bahwa manusia hanyalah mesin saja. Manusia berbeda dengan ciptaan yang lain justru karena manusia memiliki kepribadian. Dan karena manusia memiliki kepribadian maka manusia memiliki hubungan khusus dengan Allah dibanding ciptaan Allah yang lain. ${ }^{11}$

Pandangan semesta Kristen meyakini bahwa penciptaan oleh Tuhan bukan kesatuan yang tidak dapat dipisahkan, tetapi suatu ciptaan yang merupakan obyek, peristiwa dan pribadi yang berbeda-beda. Jika segala sesuatu adalah satu dan segala bentuk dualistis di dalam kenyataan melebur menjadi satu kesatuan kosmis, maka realitas terakhir

\footnotetext{
${ }^{11}$ Francis A. Schaeffer, The Complete Works of Francis A. Schaeffer: A Chirstian View of Philosophy And Culture, Vol. 1, 2, Dan Vol. 5 (Illinois: Crossway Books, 1982), 102.
}

adalah allah yang di dalam semua dan melalui semua; dan kemudian allah adalah semua.

Tao menurut To Thi Anh berarti jalan, dalam arti yang luas dimaknai sebagai akal budi, logos. ${ }^{12}$ Namun logos yang dimaksudkan bukanlah firman yaitu Allah. Secara Alkitabiah dalam penciptaan dipahami bahwa Allah itu terpisah dari ciptaan-Nya. Bukan seperti keyakinan Taois yang menempatakan Tao sebagai ibu dari segala yang nyata di dunia ini. Atau dengan kata lain bahwa semua yang ada di dunia ini dilahirkan oleh Tao yang satu itu. ${ }^{13}$ Gambaran keterpisahan antara Allah dan ciptaanNya yang diberikan oleh Schaeffer ini dilukiskan lebih jauh oleh Bromiley sebagai berikut:

God is not just an architect of builder who works with what is at hand. Nor is creation an emanation from God. Nor is it a natural product in the sense that a child is procreated by its parents. There is no organic connection between God and the cosmos... in the NT the variants of "from beginning (or "foundation") of the

\footnotetext{
12 To Thi Anh, Nilai Budaya Timur Dan Barat Konflik Atau Harmoni? (Jakarta: PT. Gramedia, 1984), 12.

${ }^{13}$ Kent Kedl and Dean C. Halverson, The Compact Guide To World Religions:

Understanding and Reaching Followers Of Islam, Buddhism, Hinduism, Taoism, Judaism, Secularism, The New Age and Other World Faiths (Minneapolis: Bethany House Publishers, 1996), 220.
} 
world" (Mrk. 10:6; Rm. 1:20; 2Pet. 3:4) indicate plainly that the world as a totality had a beginning. They no place for preexistent matter, and the stress on God's positive action leaves no place for emanation. ${ }^{14}$

Allah benar-benar menciptakan dunia dan semua isinya dari apa yang tidak ada pada suatu waktu tertentu dan di luar dari diri-Nya. Allah tidak melebur ataupun menjadi satu esensi dengan ciptaan-Nya.

Manusia Diciptakan Oleh Allah Tetapi Manusia Bukanlah Allah

Alkitab menyaksikan bahwa manusia diciptakan oleh Allah. Kenyataan bahwa manusia diciptakan berarti manusia tidak mempunyai eksistensi sendiri. Manusia ada karena Allah yang menghendakinya. Manusia diciptakan segambar dan serupa dengan Allah, tetapi manusia tetap bukanlah Allah, karena kita tidak seesensi dengan Allah. Kepribadian Allah berbeda dengan kepribadian manusia, karena kepribadian Allah adalah asli sedangkan kepribadian kita adalah pemberian. Groothuis mengutip penjelasan Frame bahwa manusia merefleksikan Pencipta kita di dalam hal, seperti Dia, kita adalah pribadi

${ }^{14}$ Geoffrey W. Bromiley, The International Standard Bible Encyclopedia Vol. A-D (Grand Rapids: Williams B. Eerdmans Publishing Company, 1979), 803. kita berpikir, merasa dan bertindak. Tetapi kita terbatas dan berpribadi, dimana Allah tidak terbatas dan berpribadi. $^{15}$

Oleh sebab itulah, sekalipun manusia memiliki daya cipta melampaui makhluk ciptaan Allah yang lain, bahkan bila ia berhasil meramu formula untuk mempertahankan hidupnya di dunia, semuanya bersifat sementara. Manusia tidak dapat menyentuh dimensi rohaninya yang telah mati. Manusia adalah ciptaan Allah dan bukan mengalir dari Allah. Manusia bukan bagian dari keallahan. Manusia dibatasi oleh kefanaan. Manusia tidak mengetahui segala sesuatu, dan dia juga tidak dapat melakukan segala sesuatu. Kekristenan adalah berpadu secara rohani dengan Alah, walaupun secara metafisik manusia akan senantiasa terpisah dari Allah seperti apa yang telah dijelaskan Schaeffer.

C. S. Lewis membedakan kehidupan biologis dan kehidupan spiritual yang dimiliki manusia untuk menyatakan bahwa kehidupan yang dimiliki oleh manusia dengan kehidupan yang dimiliki Allah adalah dua hal yang berbeda. Ia menggunakan kata bios dan

${ }^{15}$ Groothuis, Membuka Topeng Gerakan Zaman Baru, 25. 
zoe untuk membedakan dua jenis kehidupan ini.

Kehidupan biologis yang diberikan kepada kita melalui alam, dan yang (seperti segala yang lain dalam alam) selalu cenderung rusak dan membusuk sehingga kehidupan itu hanya bisa dipertahankan oleh subsidisubsidi yang tidak pernah berhenti dari alam dalam bentuk udara, air, makanan dan sebagainya, adalah bios. Kehidupan spiritual yang ada di dalam diri Allah dari kekekalan dan yang menjadikan seluruh alam semesta adalah Zoe. ${ }^{16}$

Jadi manusia dalam kondisi naturalnya tidak memiliki kehidupan rohani (seperti yang dimiliki oleh Allah). Hanya ketika Allah menghembuskan nafas hidup ke dalam hidungnya manusia menjadi hidup. Namun sebagaimana yang telah diuraikan di depan bahwa karena pemberontakannya kepada Allah, manusia itu menjadi mati secara rohani. Ia hanya makhluk bios yang mewarisi gambar dan rupa Allah di dalam dirinya. Bahkan karena dosanya manusia bukan hanya akan mengalami kematian fisik, tetapi juga kematian kekal.

Fengshui

mengusahakan pelestarian hidup manusia dalam keseimbangan dengan alam di sekitarnya.

${ }^{16}$ C. S. Lewis, Mere Christianity (Bandung: Pionir Jaya, 2006), 223.
Tujuannya adalah dengan usaha-usaha penataan diri terhadap lingkungannya manusia dapat beroleh selamat di dunia ini. Inilah keselamatan dalam pandangan Fengshui, manusia harus berusaha untuk menolong dirinya sendiri sehingga ia dapat bertahan hidup lebih lama di dunia ini dengan menarik manfaat dari lingkungannya.

Hal yang terlupakan dalam konsep ini adalah bahwa manusia bukan hanya hidup di dunia sekarang ini saja, karena eksistensi kekal yang telah diberikan kepada Allah ada di dalam dirinya, ia harus menghadapi dua kenyataan. Jika ia mati dalam keberdosaannya maka ia akan menghadapi penghakiman kekal, namun jika ia telah dilahirkan kembali oleh Roh maka ia mendapat bagian dalam hidup yang kekal bersama dengan Allah (Yoh. 3:3). dan faktanya bahwa manusia tidak dapat menolak kematian yang menghampirinya, kapan saja.

Manusia tidak mungkin menemui jati dirinya dengan beranggapan bahwa dirinya serta kebahagiaannya adalah nilai yang tertinggi. Nilai yang dimiliki oleh manusia diberikan oleh pihak yang lebih tinggi kedudukannya. Oleh sebab itulah kepuasan dan kebahagiaan manusia hanya teijadi jika ia mengasihi Oknum 
yang lebih tinggi itu. Manusia hanya mengalami kemanusiaannya secara utuh bila ia berhubungan secara benar dengan Allah, Sang Pencipta-Nya.

Alam dalam pandangan Fengshui posisinya tidak jauh berbeda dengan manusia. Karena di dalam alam diyakini berdenyut nadi kehidupan. Di dalam pepohonan dan batu- batuan, tanah, air dan udara beredar azas yang sama yakni Chi. Energi pada Chi berbeda dengan energi pada penciptaan langit dan bumi dengan segala isinya, karena karya tersebut hanya dikerjakan oleh Allah sendiri. Suatu karya penciptaan dari yang tidak ada menjadi ada terjadi pada langit dan bumi, dalam bahasa Ibrani digunakan istilah Bärä'. ${ }^{17}$ Itulah sebabnya ajaran tentang Fengshui mengajarkan manusia untuk menghormati alam, manusia ada tidak untuk mengalahkan alam. Karena manusia adalah satu dengan alamnya. Inilah yang dimaksud dengan $W u$ Wei dalam filosofi Fengshui. Taoisme percaya bahwa kebijaksaan adalah mengetahui kesulitan-kesulitan dan tidak pernah mempunyai sikap agresif terhadap kodrat alam dan manusia. Taoisme menekankan ketidaksadaran, intuisi,

\footnotetext{
${ }^{17}$ Hannas, Teologi Sistematika II: Angelologi, Satanalogi, Demonologi, Antropologi, Hamartologi, ed. Rinawaty (Tangerang: Yayasan Kharis Indonesia, 2018), 62.
}

sikap spontan, aliran yang tak bertenaga dari pikiran dan tindakan, menurut taoisme kedamaian terjadi apabila orang tidak mencampuri jalan kodrat.

Tujuan dari Fengsui adalah untuk membuka Chi dunia, agar dapat/bisa mengalir tanpa hambatan. Sama halnya dengan tujuan pengobatan tradisional tusuk-jarum, yang membuka Chi di tubuh manusia. Seorang pakar Fengsui harus mencari suatu tempat yang cocok agar Chi mengalir lancar, unsur Yin dan Yang seimbang. Bila tak berhasil melakukan hal itu, takkan dapat mendekatkan manusia dengan alam. ${ }^{18}$

Alam dalam pengajaran Fengshui sangat berkaitan erat dengan nasib manusia. Konfigurasi alam di sekitar lingkungan hidup manusia akan mengungkap kehadiran $C h i$ yang baik atau Sha Chi (Chi yang buruk). Jika terlalu banyak titik akumulasi Chi buruk, maka mempengaruhi peruntungan hidup manusia yang tinggal di sekitar daerah tersebut.

Gunung-gunung diyakini sebagai tempat di mana dewa-dewa

\footnotetext{
${ }^{18}$ Shen Sien Siao and Evelyn Lip, Orientasi Dan Manfaat Hong Sui: Tata Letak Bangunan Berpotensi 'Chi' Sejati (Jakarta: Bhuana Ilmu Populer, 2008), 9.
} 
bersemayam ${ }^{19}$ dan diyakini juga sebagai tempat tinggal naga. Tanah pegunungan dianggap sebagai sumber asli dan energi vital Yang, dan suatu pokok perwujudan alami yang paling perkasa dan jantan, tempat yang layak bagi sarang sang naga. Sebab gunung-gunung membentuk tempat-tempat pengasingan yang hampir tidak tercapai oleh manusia, dan ideal sebagai tempat persembunyian naga. Karena itu tinggal di tanah yang datar dan rata merupakan wilayah yang paling tidak menguntungkan. Namun para penganut Fengshui tidak konsisten ketika menggantikan gunung dengan gedunggedung beton di perkotaan.

Dalam Fengshui diyakini ada lima unsur alam, yakni api, tanah, logam, air dan kayu. Dalam rotasinya ${ }^{20}$ kelima unsur ini mempengaruhi kesejahteraan manusia. Karena dalam keyakinan Fengshui (dari Taoisme) segala kegiatan di bumi selalu mempengaruhi langit, ${ }^{21}$ dan demikian juga secara timbal balik langit akan mempengaruhi segala

\footnotetext{
${ }^{19}$ Stephen Skinner, Feng Shui Ilmu Tata Letak Tanah Dan Kehidupan Cina Kuno (Semarang: Dahara Prize, 1997), 80.

${ }^{20}$ Rotasi kelima unsur ini terkadang disebut siklus rotasi energi, Lihat Hua, Tao: Pedoman Hidup Selaras Dengan Hukum Alam, 26.

${ }^{21}$ Langit yang dimaksud di sini bukan langit secara fisik tetapi menyatakan kuasa yang tertinggi dari dunia ini. Dalam keyakinan Taois disebut sebagai T'ien, lihat P. J. Maclagan, Encyclopedia of Religion and Ethic, Vol. XII (Edinburgh: T. \& T. Clark, 1922), 198.
}

keadaan di bumi. Sebagai contoh, sejak jaman dahulu diyakini bahwa sifat-sifat Kaisar Cina mempengaruhi sifat kosmos. Kaisar-kaisar yang jahat menciptakan ketidakstabilan di Cina dan dalam kosmos. Pemerintahan Kaisar yang baik ditandai oleh keselarasan dalam masyarakat Cina, alam dan dunia secara keseluruhan. ${ }^{22}$

Interaksi langit dan bumi ini di dalam Fengshui kemudian dikondisikan atau dimodifikasikan oleh siklus lima unsur tersebut. Ketika semesta bersiklus, energi universal (Chi) menempuh tahaptahap transformasi. Oleh karena itu seseorang harus mengetahui berbagai unsur yang menjadi ciri Shio-nya (unsur yang mengatur tahun kelahirannya), supaya ia dapat merencanakan waktuwaktu yang baik sesuai dengan rotasi energi tersebut dengan faktor hidup bawaannya. Itulah sebabnya para ahli Fengshui menggunakan astrologi ${ }^{23}$ Cina

\footnotetext{
22 David W. Shenk, Global Gods Exploring The Role of Religions In Modern Societies (Pennsylvania: Herald Press, 1995), 174.

23 Pengamatan terhadap bintang, komet dan planet telah dipelajari sejak dahulu kala. Bendabenda angkasa dianggap sebagai dewa-dewa yang dapat mempengaruhi atau memberi isyarat tentang hal-hal yang akan terjadi dibumi. Bahkan penyembahan terhadap benda-benda angkasa dilakukan karena benda-benda tersebut dianggap beredar dalam sebuah lingkaran yang sempurna. Prof. Heath dalam Sains, Iman dan Teknologi (Yogyakarta: Yayasan ANDI, 1997) mengungkapkan ketidakteraturan rotasi bendabenda langit ini. Beliau juga memaparkan bahwa
} 
sebagai salah satu tetapan dalam nasib seseorang.

Nasib seseorang dapat ditentukan atau diubah jika seseorang memiliki kunci untuk mempengaruhi perubahan. Untuk itu dibutuhkan pemahaman cara kerja (rotasi energi) alam dan hubungan manusia dengan lingkungannya. ${ }^{24}$

\section{Nasib Manusia Tidak Bergantung}

\section{Pada Alam}

Alam ini diciptakan oleh Allah dalam kondisi yang sangat baik. Hal ini dapat dilihat dari setiap pernyataan Allah bahwa Allah melihat apa yang diciptakan-Nya itu baik (Kej. 1:10, 12, 17, 21). Bahkan manusia diberi mandat oleh Allah untuk memelihara dan mengelola alam (Kej. 1:28). Bukan membiarkan alam itu berjalan sesuai dengan kodratnya seperti sikap $W u W e i$.

Karena ketika manusia jatuh ke dalam dosa dan dikutuk Allah kutuk itu juga berdampak pada alam di mana

astronomi kini menunjukkan terjadinya perubahan bertahap pada susunan antariksa. Bahwa planet-planet yang terlihat sekarang tidak terdaftar pada susunan astrologis kuno, karena planet-planet bertambah jumlahnya jaman demi jaman dimana komet-komet yang memasuki susunan matahari satu demi satu tertangkap oleh medan gravitasinya. Pembuktian dari Ilmu Pengetahuan Alam ini jelas membantah "ketetapan astrologi" yang digunakan oleh para praktisi Fengshui.

${ }^{24}$ Markus T. Suryanto, Cap Jie Shio Hong

Shui/Feng Shui Dan Kekristenan (Jakarta:

Pelkrindo, 1999), 113. manusia tinggal. Sebagaimana yang telah dijelaskan dalam bab tiga melalui grafik panah waktu Eddington, energi bumi kian merosot hari demi hari dan pada satu masa nanti akan menuju kebinasaannya. Penyusutan alam ini merupakan akibat langsung dari kejatuhan manusia ke dalam dosa di mana alam semesta turut merosot karena keberdosaan Adam. Tanah dikutuk Allah sehingga mengalami entropi dan kehilangan kesuburannya (Kej. 3:17-19).

Bila bersikap $W u$ Wei dan membiarkan alam ini berjalan sesuai dengan kodratnya saja, itu berarti manusia tidak mau mengemban tugas yang telah diberikan Allah kepadanya. Manusia membunuh kreatifitasnya dan membiarkan alam rusak karena kemerosotannya. Apalagi tingkat entropi bumi semakin besar ketika kutuk kedua ditimpakan Allah atas bumi ini pada peristiwa banjir Nuh.

Berdasarkan kesaksian Alkitab, keturunan Adam juga turut menyakiti hati Tuhan karena ketika dilihat TUHAN, bahwa kejahatan manusia besar di bumi dan bahwa segala kecenderungan hatinya selalu membuahkan kejahatan sematamata (Kej. 6:5). Maka Allah bermaksud membinasakan bumi. Tetapi Nuh mendapat kasih karunia di mata TUHAN 
karena ia adalah seorang yang benar dan tidak bercela di antara orang-orang sezamannya; dan Nuh itu hidup bergaul dengan Allah (Kej. 6:8-9). Karena itu Allah bermaksud menyisakan Nuh dan keturunannya saja.

Peristiwa air bah telah menyebabkan kerusakan alam yang sangat nyata. Dan menyebabkan penghancuran dan pembentukan ulang kerak bumi bahkan bukan hanya lapisanlapisan yang ada tetapi juga pegunungan terbentuk sejak air bah. ${ }^{25}$ Ketidakseimbangan tektonis terjadi ketika air menutupi bumi selama satu tahun dan menaikkan gunung-gunung sampai ke atas permukaan samudera. Bahkan Alkitab melaporkan bahwa pada jaman Peleg benua-benua berpisah satu dengan yang lain (Kej. 10:25).

Peristiwa-peristiwa bencana alam akhir-akhir ini intensitasnya bertambah terus. Gempa bumi dalam skala yang besar satu tahun berturut-turut melanda Indonesia, sementara badai terusmenerus melanda benua Amerika. Musim-musim berganti tidak tepat lagi pada masanya, sehingga di satu bagian bumi teijadi kekeringan yang parah,

${ }^{25}$ W. Stanley Heath, Tafsir Kitab Kejadian Pasal 1-11: Relevansinya Dengan Pemulihan Gereja Di Akhir Zaman (Yogyakarta: Yayasan ANDI, 1998), 100. sementara di bagian yang lain airnya melimpah dan bahkan terjadi banjir.

Apa yang terjadi pada alam ini merupakan dampak yang berkepanjangan karena kemerosotan alam. Kemerosotan alam ini bermula dan terjadi ketika manusia memberontak pada Allah sehingga ia dikutuk dan tanah tempat ia hidup di kutuk. Kondisi ini berlawanan dengan apa yang diyakini dalam Fengshui bahwa kesejahteraan manusia bergantung pada alam. Dan telah tampak nyata bahwa sangatlah tidak mungkin untuk mengharapkan keseimbangan alam. Alam tidak akan berangsur-angsur semakin baik, tetapi alam akan menuju kebinasaannya. Kebinasaan alam telah teijadi karena keberdosaan manusia dan karena itu tidak mungkin untuk menggantungkan nasib hidup (Wu Wei) kepada alam yang akan binasa.

\section{Alam Semesta Diciptakan Untuk Kemuliaan Allah}

Alam semesta ini diadakan oleh Allah untuk kemuliaan-Nya. Yang pertama karena manusia sebagai makhluk ciptaan Allah yang tertinggi diperintahkan Allah untuk mengelola alam semesta ini. Yang kedua karena alam menceritakan kemuliaan Allah. Allah menciptakan dunia ini dengan teratur dan untuk dunia yang sudah diatur 
ini Allah menetapkan manusia untuk mengelola dan mengusahakan alam ini. Mandat yang diemban manusia merupakan pemenuhan dari kesegambarannya dengan Allah. Allah memberkati manusia, artinya Ia telah memberikan kemampuan (daya cipta) kepada manusia untuk melakukan tugasnya di dunia ini. Inilah tujuan Allah menciptakan manusia dalam gambar dan rupa-Nya supaya manusia dapat mewakili Allah di dunia ini untuk memerintah dan menguasai bumi.

Allah juga yang menetapkan dengan cara bagaimana manusia harus memberlakukan alam ini. Schaeffer katakan:

God is there! The personalinfinite God is the universal of all the particulars; an in His verbalized, proportional communications in the Scripture He has given us categories within which to treat everything within His creation: man to man, man to nature, the whole lot. ${ }^{26}$

Alam ini penting dalam pandangan Pencipta-Nya dan Allah juga mau manusia memandang alam ini penting untuk dirinya. Bukan semata-mata karena manusia memperoleh makanannya dari alam, tetapi supaya manusia juga dapat

${ }^{26}$ Schaeffer, The Complete Works of Francis A. Schaeffer: A Chirstian View of Philosophy And Culture, Vol. 1, 2, Dan Vol. 5, 52. memandang alam sama seperti dirinya sebagai ciptaan Allah.

Tumbuhan, hewan dan manusia dibuat sedemikian rupa sehingga dapat memperoleh makanan yang diperlukan, bertumbuh, dan berkembang biak. Matahari, bulan dan bintang telah ditempatkan dalam lintasannya untuk mengatur pergantian siang dan malam serta pertukaran musim di bumi. Kondisi ini mensyaratkan adanya perancang atau penyebab yang berakal budi tinggi, bebas, berada di luar alam semesta serta akbar adanya.

Allah menciptakan dunia dan segala sesuatu dengan tujuan untuk dirinya sendiri (Rm. 11:36). Dunia diciptakan Tuhan bukan tanpa sasaran, alam semesta ini diciptakan dalam konsep dan rancangan Pencipta-Nya. Karena Allah bukan sekedar oknum yang berkepribadian, namun Ia juga tidak terbatas kebijaksanaan-Nya, kemurahan dan kuasa-Nya, namun juga adalah Pencipta dan oleh karenanya pemilik alam semesta, maka dengan sendirinya dapat diharapkan bahwa Ia akan memerintah apa yang dimilikiNya itu. ${ }^{27}$ Kesaksian Alkitab mengatakan bahwa akan datang suatu masa pemerintahan

\footnotetext{
${ }^{27}$ Stephen Tong, Mengetahui Kehendak Allah (Surabaya: Momentum, 1999), 29.
} 
Allah dalam masa seribu tahun di bumi (Kerajaan Millenium) (Wah. 20:1-6; Rom. 8:19-23; Yes.11:1-10). Di masa ini kutuk Allah atas bumi diangkat, manusia hidup normal kembali seperti pada masa di mana belum ada dosa di dunia. Namun sebelum masa itu tiba, sekarang di masa kini alam juga turut menyatakan kemuliaan Allah.

Langit menceritakan kemuliaan Allah, dan cakrawala memberitakan pekerjaan tanganNya; hari meneruskan berita itu kepada hari, dan malam menyampaikan pengetahuan itu kepada malam. Tidak ada berita dan tidak ada kata, suara mereka tidak terdengar; tetapi gema mereka terpencar ke seluruh dunia, dan perkataan mereka sampai ke ujung bumi. Ia memasang kemah di langit untuk matahari, yang keluar bagaikan pengantin laki-laki yang keluar dari kamarnya, girang bagaikan pahlawan yang hendak melakukan perjalanannya. Dari ujung langit ia terbit, dan ia beredar sampai ke ujung yang lain; tidak ada yang terlindung dari panas sinarnya (Maz. 19:2-7).

Lewat mazmur ini Daud menyatakan kekagumannya akan Allah dengan menyaksikan ciptaan Allah yang ada dalam alam semesta ini. Inilah salah satu tujuan Allah, agar melalui ciptaan-Nya Ia dimuliakan. Paulus juga menegaskan seyogyanya manusia mencari dan memuliakan Allah karena alam ini telah menjadi saksi dari karya tangan-Nya (Rm. 1:19-21).

Jika kita mau memikirkan kehendak Allah dengan tuntas maka kita harus mengelola alam semesta dan bukan untuk merusaknya. Tanggung-jawab terhadap dunia yang diciptakan Allah telah dibebankan kepada manusia.

Fengshui meyakini bahwa langit dan bumi kekal adanya. Energi semesta tak dapat diukur dan tak terkira. Energi semesta berada di luar waktu dan tempat. Segala hal yang terlihat dan tak terlihat ada di dalamnya. Jadi energi semesta ada dan kekal, meskipun tak terlihat. ${ }^{28}$

Keyakinan Fengshui meyakini bahwa alam semesta adalah materi yang utama. Karena baik manusia maupun alam merupakan pernyataan dari Chi yang memadat dan Chi yang paling lemah adalah Chi manusia, sementara alam menyimpan Chi yang besar. ${ }^{29}$ Langit dan bumi abadi karena langit dan bumi tidak hidup untuk dirinya sendiri. ${ }^{30}$ Alam diasosiasikan seperti air; air memberikan faedah kepada segala benda, maka dengan demikian alam mendekati "jalan" (Tao). Alam diyakini abadi

\footnotetext{
${ }^{28}$ Hua, Tao: Pedoman Hidup Selaras Dengan Hukum Alam, 3.

${ }^{29}$ Michael Page, Energi Chi: Hidup Sukses Sesuai Filosofi Timur (Jakarta: Abdi Tandur, 1996), 5.

30 Tjoe Som Tjan, Tao The Ching (Jakarta: Bhratara, 1962), 12.
} 
karena alam mengalirkan "hidup" bagi semua yang ada di dalam semesta.

Selain kekekalan alam, dalam Fengshui juga manusia mencari kekekalan jasmani atau yang lebih tepat adalah keawetan tubuh jasmani/panjang umur di dunia. Hal ini dilatar-belakangi oleh keyakinan bahwa di suatu daerah yang jauh ada satu pulau yang indah dan barangsiapa yang berhasil menjejakkan kakinya di tempat itu akan beroleh hidup kekal (long life). Tetapi karena tidak ada yang berhasil menemukan pulau tersebut, maka mereka mencoba menciptakan sejenis pil yang membuat orang hidup selama-lamanya dan tetap remaja. ${ }^{31}$

Di masa kini Fengshui menawarkan kehidupan yang panjang lewat sexual hygiene, menu makanan tertentu, yoga dan meditasi. Harapannya dengan cara-cara demikian usia manusia akan lebih panjang dan fisiknya akan lebih awet muda.

\section{Bumi dan Segala Isinva Memiliki Awal dan Akhir}

Semua materi yang ada di dunia ini telah diadakan oleh Sang Pencipta dalam enam hari penciptaan dunia. Kejadian pasal 1 mengisahkan penciptaan alam semesta oleh Allah

${ }^{31}$ Joesoef Sou'yb, Agama-Agama Besar Di Dunia (Jakarta: Pustaka Alhusna, 1983), 200. sebagai Pelakunya. Materi tidak ada atau jadi dengan sendirinya. Materi tidak bersifat kekal karena materi diadakan oleh Allah juga.

Kejadian 3 meriwayatkan pemberontakan Allah atas manusia. Meskipun Adam dan Hawa telah diberi mandat untuk mewakili Allah di bumi ini, namun mereka melanggar ketetapan Allah dan memilih berpihak kepada Iblis. Pelanggaran Adam dan Hawa ini membawa malapetaka yang pertama atas manusia dan juga atas alam yang telah “diserahkan” Allah pada manusia.

Dampak murka Allah atas alam dapat dilihat juga dalam hukum penyusutan (entropi). Entropi mengungkapkan kenyataan bahwa segala sesuatu, yang hidup atau pun yang bendawi senantiasa merosot. Penciutan bumi yang mengakibatkan gempa dan gunung berapi adalah bukti yang jelas dari penyusutan tersebut. ${ }^{32}$

Kekekalan zat bukan hanya menjadi azas metafisis Fengshui tetapi juga bagi sains modern. Heath mengungkapkan bahwa penyelidikan yang sedalam dan seluas mungkin hanya menemukan adanya tiga kenyataan alam yang berlaku umum. Ketiga

\footnotetext{
${ }^{32}$ Heath, Tafsir Kitab Kejadian Pasal 1-11: Relevansinya Dengan Pemulihan Gereja Di Akhir Zaman, 29.
} 
prinsip/hukum dasar ini disebut ketiga hukum termodinamika (ilmu panas): (1) Jumlah zat energi konstan dan tak tergugat, (2) potensi alam serta isinya senantiasa merosot, (3) keadaan lampau tak terpulihkan. ${ }^{33}$ Jadi berdasarkan pengamatan ilmiah terhadap alam maka zat itu fana.

Dunia yang telah tercemar oleh dosa ini akhirnya akan dibinasakan oleh api (2 Pet. 3:12). Gambaran tentang hangusnya bumi oleh api ini dapat dibayangkan lebih jelas berdasarkan penyusutan daya magnetis bumi. Medan magnetis benda-benda angkasa termasuk bumi sedang merosot, hal ini menyebabkan planet-planet lain dan bumi pada suatu waktu akan sampai kepada batas minimal magnetisnya sehingga menyebabkan bumi akan terlempar dari porosnya masuk ke dalam matahari. ${ }^{34}$ Langit dan bumi ini akan berlalu, oleh karena itu maka proses alam juga tidak bersifat kekal.

\section{Manusia Hanya Beroleh Kekekalan}

Jika Hubungan Manusia dan

\section{Pencipta-Nya Kembali Dipulihkan}

Manusia ketika dibentuk hanyalah debu tanah sampai Allah meniupkan nafas hidup kepadanya. Oleh sebab itulah

\footnotetext{
${ }^{33}$ Ibid, 74.

${ }^{34}$ Ibid, 79-80.
}

manusia menjadi makhluk yang hidup dan saat itu juga manusia beroleh eksistensi kekekalan Allah di dalam dirinya. Namun Alkitab mengisahkan bahwa manusia kemudian berontak kepada Allah. Sebagaimana peringatan yang telah diberikan Tuhan, maka ketika mereka melanggar perintah Tuhan dengan memakan buah pohon pengetahuan yang baik dan yang jahat itu, maka seketika itu juga manusia mati. Kematian manusia ini bermakna terenggutnya hak istimewa manusia untuk hidup bersekutu dengan Allah selama-lamanya.

Pada saat itu secara fisik manusia tidak langsung mati, tetapi eksistensi rohaninya telah mati seketika itu juga. Eksistensi kekekalan manusia berpindah tempat dari kemuliaan Allah kepada penghukuman yang kekal, dari hidup ke dalam maut. Di saat manusia jatuh dalam dosa ia kehilangan tiga hal penting dalam hidupnya: (1) hak untuk tinggal dalam taman Eden, (2) persekutuan yang indah dengan Tuhan Allah, (3) kehidupan yang kekal bersama dengan Allah.

Oleh sebab itu kondisi manusia kini berbeda dari manusia pertama sebelum mereka jatuh ke dalam dosa. Ada dua tipe manusia pada masa kini yaitu mereka yang mau percaya kepada 
karya Kristus dan menerima-Nya sebagai Juruselamat pribadi dan mereka yang menolak-Nya. Apabila seseorang menerima Yesus maka ia memperoleh kelahiran baru dan dibaptis oleh Roh Kudus (Ef. 1.13). Statusnya berubah dari yang harus binasa menjadi diselamatkan dan memiliki hidup yang kekal (Yoh. 5:24). Hubungannya dengan Allah dipulihkan.

Jadi manusia yang hubungannya dengan Sang Pencipta telah dipulihkan ia memiliki kembali eksistensi kekalnya untuk bergaul dengan Allah, seperti yang dimiliki manusia pertama sebelum mereka jatuh ke dalam dosa. Kekekalan ini diperoleh manusia karena perubahan status dan bukan karena berbuat baik. Derajat eksistensi kekal yang dimiliki orang percaya saat ini memang lebih rendah daripada manusia pertama. Karena mereka telah memiliki realisasinya, sedangkan orang percaya pada masa kini belum memiliki realisasi itu.

Tetapi kondisi ini sifatnya hanya sementara, karena manusia masih hidup di dalam tubuhnya yang fana dan di dalam dunia yang fana. Kekristenan meyakini bahwa pada suatu saat Yesus akan datang kembali. Manusia yang percaya pada Yesus yang telah mati akan dibangkitkan dan diberi tubuh yang baru, sementara yang masih hidup sampai pada waktu Yesus datang akan diubahkan seketika untuk menyongsong Yesus di angkasa (1 Kor. 15:12-26; 52-58; 1 Tes. 4:13-18).

Perjalanan untuk mengalami eksistensi kekal dalam hubungan dengan Allah di mulai dan akan berlangsung sampai kekal, di surga dan bumi yang baru. Itulah sebabnya Paulus berkata bahwa ia terlebih suka untuk meninggalkan dunia ini dan bersama dengan Allah saja (Fil. 1:21). Karena orang percaya hanya bisa mencicipi kenikmatan dan keindahan hidup dalam persekutuan dengan Tuhan di dalam tubuh yang fana, tetapi jika ia beralih dari tubuhnya ini (mati) dan kelak ketika tubuhnya diubahkan maka manusia akan berhadapan muka dengan muka kepada Allah.

Itulah sebabnya usaha untuk mempertahankan hidup lebih panjang di dunia yang fana ini bukan saja merupakan usaha "menjaring angina" tetapi juga merupakan sebuah kerugian. Sebab alam sedang menuju kepada kebinasaannya, tinggal di bumi ini lebih lama lagi berarti merasakan segala dampak dari kemerosotan alam. Disisi yang lain manusia yang tidak percaya 
juga akan binasa karena menolak karya

Kristus di kayu salib. Itu berarti mereka menolak keselamatan kekal yang telah ditawarkan kepada mereka.

\section{KESIMPULAN}

Langit dan bumi diciptakan Allah dari tidak ada menjadi ada. Hal ini membuktikan bahwa Allah Maha Kuasa adanya. Penciptaan yang dilakukan-nya menunjukkan bahwa Allah terpisah dari ciptaan-Nya. Penciptaan alam semesta tidak dapat ditentukan pada waktu tertentu, sekalipun tidak bersifat kekal. Allah sebagai pencipta kekal adanya, sedangkan alam semesta yang diciptakan tidak bersifat kekal. Manusia diciptakan segambar dan serupa dengan Allah. Manusia Adam dan Hawa diberi kuasa untuk menata atau mengelola isi alam semesta, dan semestinya taat pada perintah-Nya. Namun Manusia telah jauh dalam dosa dan akibatnya terpisah (terputus) hubungannya dengan Allah untuk selama-lamanya. Alam semestinya yang diciptakan Allah tidak bersifat kekal dan pengajaran Fengshui yang menekankan untuk mempertahankan hidup lebih panjang di dunia tidak bertentangan dengan takdir Allah. Karena kehidupan kekal hanya dapat diperoleh manusia bila menerima pengampunan dari Allah yang terfasilitasi hanya melalui penebusan Yesus Kristus.

\section{DAFTAR PUSTAKA}

Anh, To Thi. Nilai Budaya Timur Dan Barat Konflik Atau Harmoni? Jakarta: PT. Gramedia, 1984.

Bromiley, Geoffrey W. The International Standard Bible Encyclopedia Vol. $A-D$. Grand Rapids: Williams B. Eerdmans Publishing Company, 1979.

Brow, Robert. "Religion of China." In The Great Asian Religions An Anthology. New York: MacMillan Publishing Company, 1986.

Burson, Scott R. The New International Dictionary of New Testament Theology Vol. 1. Grand Rapids, Michigan: Zondervan Publishing Company, 1998.

Groothuis, Douglas. Membuka Topeng Gerakan Zaman Baru. Jakarta:

Stephen Tong Evangelistic Ministries International, 1996.

Hannas. Teologi Sistematika II: Angelologi, Satanalogi, Demonologi, Antropologi, Hamartologi. Edited by Rinawaty. Tangerang: Yayasan Kharis Indonesia, 2018.

Heath, W. Stanley. Tafsir Kitab Kejadian Pasal 1-11: Relevansinya Dengan Pemulihan Gereja Di Akhir Zaman. Yogyakarta: Yayasan ANDI, 1998.

Hua, Ching Ni. Tao: Pedoman Hidup Selaras Dengan Hukum Alam. Jakarta: Pustaka Delapratasa, 1997.

Kedl, Kent, and Dean C. Halverson. The Compact Guide To World Religions: Understanding and Reaching Followers Of Islam, Buddhism, Hinduism, Taoism, Judaism, Secularism, The New Age and Other World Faiths. Minneapolis: Bethany 
House Publishers, 1996.

Lewis, C. S. Mere Christianity. Bandung: Pionir Jaya, 2006.

Maclagan, P. J. Encyclopedia of Religion and Ethic, Vol. XII. Edinburgh: T. \& T. Clark, 1922.

McGrath, Alister E. Bridge Building: Efective Christian Apologetics. England: Hodder and Stoughton Ltd., 1992.

Page, Michael. Energi Chi: Hidup Sukses Sesuai Filosofi Timur. Jakarta: Abdi Tandur, 1996.

Rinawaty. Apologetika Kristen Terhadap Kosmologi Fengshui. Edited by Hannas. Tangerang: Yayasan Kharis Indonesia, 2017.

Schaeffer, Francis A. The Complete Works of Francis A. Schaeffer: A Chirstian View of Philosophy And Culture, Vol. 1, 2, Dan Vol. 5. Illinois: Crossway Books, 1982.

Shenk, David W. Global Gods Exploring The Role of Religions In Modern Societies. Pennsylvania: Herald Press, 1995.

Siao, Shen Sien, and Evelyn Lip. Orientasi Dan Manfaat Hong Sui: Tata Letak Bangunan Berpotensi 'Chi' Sejati. Jakarta: Bhuana Ilmu
Populer, 2008.

Skinner, Stephen. Feng Shui Ilmu Tata Letak Tanah Dan Kehidupan Cina Kuno. Semarang: Dahara Prize, 1997.

Sou'yb, Joesoef. Agama-Agama Besar Di Dunia. Jakarta: Pustaka Alhusna, 1983.

Suryanto, Markus T. Cap Jie Shio Hong Shui/Feng Shui Dan Kekristenan. Jakarta: Pelkrindo, 1999.

Tanudjaja, Rahmiati. "Apologetika Kristen : Tanggung Jawab Semua Anak Tuhan." Veritas : Jurnal Teologi dan Pelayanan 6, no. 2 (October 1, 2005): 229-238.

Tjan, Tjoe Som. Tao The Ching. Jakarta: Bhratara, 1962.

Tong, Stephen. Mengetahui Kehendak Allah. Surabaya: Momentum, 1999.

Too, Liliana. Fengshui: Memasuki Dunia Naga Dan Macan Membagi Rahasia Di Tycoon Bisnis Di Asia. Jakarta: PT. Elex Media Komputindo, 1984.

"Fengshui - Pengetahuan Atau Kepercayaan?" Accessed October 20, 2019. https://interiorkantor.com/fengshuipengetahuan-atau-kepercayaan/. 